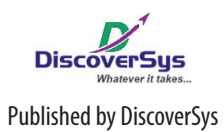

Published by DiscoverSys

\section{Emotional support is the only social support associated with the quality of life of people living with HIV}

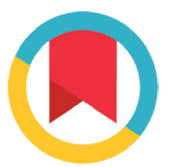

CrossMark

Ni Wayan Sri Rahayuni, ${ }^{1 *}$ Ketut Tuti Parwati Merati, ${ }^{2}$ Dewa Nyoman Wirawan, ${ }^{3}$

\title{
ABSTRACT
}

Background and purpose: The quality of life of people living with HIV is influenced by many factors, one of which is social support. Social support consists of four elements, namely information, instrumental, emotional and appraisal supports. Publication on the association between the quality of life of people living with HIV and the four elements of social support shows inconsistent results. The purpose of this study is to determine the association between the four elements of social support and the quality of life of people living with HIV.

Methods: A cross-sectional survey was carried out at the WM Medika Clinic, Kerti Praja Foundation, Denpasar, Bali. Samples were people living with HIV who came to the clinic between July-August 2018 to take antiretroviral (ARV) drugs. The total number of samples was 92 patients selected through the convenience sampling. Data was collected by conducting individual interviews and consisted of respondent characteristics, quality of life, information, instrumental, emotional and appraisal supports. Data were analyzed using logistic regression to determine the association between social support and quality of life of people living with HIV.

Results: Emotional support was the only element of social support found to be significantly associated with quality of life of people living with HIV with $A 0 R=4.918$ ( $95 \% \mathrm{Cl}: 1.268-19.082)$. Whereas the other three elements were not found to be related to the quality of life of people living with HIV, these were instrumental support $(A 0 R=0.865$; 95\%Cl: $0.228-3.278$ ); information support ( $\mathrm{AOR}=0.949 ; 95 \% \mathrm{Cl}$ : $0.248-3.637)$; and appraisal support $(\mathrm{AOR}=0.317 ; 95 \% \mathrm{Cl}$ : 0.095 1.057).

Conclusion: The quality of life of people living with HIV is found to be related to emotional support and is not found to be related to information, instrumental and appraisal supports. Emotional support needs to be addressed in order to further improve the quality of life of people living with HIV.

Keywords: Social support, quality of life, people living with HIV

Cite This Article: Rahayuni, N.W.S., Merati, K.T.P., Wirawan, D.N. 2019. Emotional support is the only social support associated with the quality of life of people living with HIV. Public Health and Preventive Medicine Archive 7(1): 38-43. D0I:10.15562/phpma.v7i1.192

'Public Health Postgraduate Program, Faculty of Medicine, Udayana University,

${ }^{2}$ Department of Internal Medicine, Faculty of Medicine, Udayana University,

${ }^{3}$ Department of Public Health and Preventive Medicine, Faculty of Medicine, Udayana University
*Correspondence to: Ni Wayan Sri Rahayuni, Public Health Postgraduate Program, Faculty of Medicine, Udayana University, niwayan.srirahayuni91@gmail.com

\section{INTRODUCTION}

In 2017 the United Nations Program on HIV/ AIDS (UNAIDS) estimated that 36.9 million people worldwide lived with HIV, and as many as 21.7 million people were taking antiretroviral therapy. ${ }^{1}$ The number of HIV-AIDS cases reported in Indonesia from 2005 to December 2017 was as many as 280,623 people, with 91,369 people were on ARV. ${ }^{2}$ The cumulative number of HIV and AIDS cases reported to the Bali Province Health Office from 1987 to December 2018 amounted to 20,392 people. ${ }^{3}$ The cumulative number of people living with HIV initiating ARVs in Bali Province until the end of December 2018 was 14,448 people, with 8,364 people remaining on the treatment. ${ }^{3}$

With the increasing number of people living with HIV using ARV, the mortality rate should decrease and the quality of life of people living with HIV improves. $^{4-6}$ Results of studies in Indonesia and several other countries indicate that the percentage of people living with HIV who stop taking ARVs is high. ${ }^{7,8}$ Social support is reported to increase compliance, reduce the possibility of therapy cessation and improve the quality of life of people living with HIV. Social support can mitigate stress that expedites the disease progression that leads to death. ${ }^{9-11}$ Social support consists of four elements, namely emotional, instrumental, informational and appraisal supports. ${ }^{12}$ Emotional support involves the provision of empathy, love, trust and care. Instrumental support involves providing a person with daily needs. Informational support includes advice, suggestions and education that assist a person when addressing their problems. Appraisal support involves the provision of self-evaluation which consists of constructive feedback and affirmation. $^{12}$

Studies on the association between social support and the quality of life of people living with HIV have been widely published with inconsistent results, and mostly focused on people living with HIV who do not take ARV. ${ }^{13-16}$ This study aims to determine the association between the four 
elements of social support and quality of life of people living with HIV using ARVs.

\section{METHODS}

A cross-sectional survey was conducted in the WM Medika Clinic at the Kerti Praja Foundation, Denpasar, Bali. The clinic has provided ARV services since 2002, before the availability of ARV services nationwide which began in 2004. ${ }^{17}$ HIV-positive people who have started ARVs at the WM Medika Clinic number at around 2000 consisting of patients both from key populations and non-key populations. HIV-positive sex workers who access ARV from the WM Medika Clinic mostly do not have families, while most men who have sex with men live far from their families.

This study focused on people living with HIV who are not identified as key populations who came to take ARVs at the WM Medika Clinic. The total samples of 92 individuals were selected through a convenience sampling from July 26 to August 27 2018. The sample size was calculated with a confidence level of $95 \%$, power $80 \%$, proportion of people living with HIV with good social support who has good quality of life of $40 \%$ and proportion of people living with HIV with poor social support who has good quality of life of $11 \% \cdot{ }^{15}$ Data collection was carried out by the researchers by conducting interviews at the WM Medika Clinic. The questionnaire consisted of respondent characteristics, quality of life, emotional, instrumental, information and appraisal supports. The quality of life questionnaire was adopted from the modified World Health Organization Quality of Life Human Immunodeficiency Virus (WHOQOL-HIV) ${ }^{18}$ consisting of 26 questions with six items. The aspects of quality of life evaluated consisted of physical health, psychological well-being, social relations, independence, environment and spirituality. Each item in the quality of life questionnaire consists of four different choices including "very often", "often", "rarely", "not at all"; (ii) "not satisfied", "less satisfied", "satisfied", "very satisfied"; (iii) "very bad", "bad", "good", "very good"; (iv) "always", "quite often", "rarely/sometimes", "never"; (v) "uncomfortable", "less comfortable", "comfortable", "very comfortable"; (vi) "not enough", "insufficient", "sufficient", "very sufficient"; and (vii) "not meaningful", "less meaningful", "meaningful", "very meaningful". The scores of each quality of life items are summed to obtain a total score and are grouped into two categories, high and low with a median value as cut off point.

The social support questionnaire was adopted from Ariesta's (2015) ${ }^{19}$ which consisted of four aspects, namely emotional, instrumental, information and appraisal supports. The social support questionnaire consists of 23 questions from four items. The social support questionnaire consists of four choices of answers namely "never", "rarely/sometimes", "often" and "always". The score for each question is added per item. The total score is obtained from the sum of the scores of each item. The scores of social support and its four aspects are categorized as "high", "medium" and "low".

Bivariate analysis for numeric data was performed with pearson correlation and Chi-square test was performed for categorical data. Multivariate analysis with logistic regression was conducted to determine the adjusted odd ratio (AOR) of each variable. This study has been approved by the Ethics Committee of the Faculty of Medicine, Udayana University/Sanglah General Hospital Denpasar Bali, on March 20, 2018.

\section{RESULTS}

Table 1 shows that most respondents are male (57.6\%), aged $35-44$ years (41.3\%), with an education of senior high school or above (59.8\%), employed (79.3\%), with duration on ARV therapy $>2$ years (78.3\%) and had ever experienced opportunistic infections (59.8\%).

In Table 2, the correlation matrix between dependent variables (quality of life of people living with HIV) and independent variables (emotional, instrumental, information and appraisal supports) is presented. It is evident that there is a strong and significant correlation between independent variables, while the correlation between independent variables and dependent variable is weak or insignificant: emotional support $(\mathrm{r}=0.267, \mathrm{p}=0.01)$, instrumental support $(\mathrm{r}=0.092, \mathrm{p}=0.39)$, information support $(\mathrm{r}=0.253, \mathrm{p}=0.02)$ and appraisal support $(\mathrm{r}=0.147, \mathrm{p}=0.16)$.

In Table 3, the association between emotional, instrumental, information and appraisal supports with quality of life is presented, with each variable converted into a categorical variable. There is no significant association between the quality of life of people living with HIV with emotional, instrumental, information and appraisal supports. However, there is a positive trend, wherein the higher the proportion of people living with HIV who receive emotional, instrumental and information support, the higher the proportion of the high quality of life of people living with HIV. There is no positive correlation between appraisal support and quality of life. In Table 4, it is evident that the only variable that was significantly related to quality of life of people living with HIV was emotional support with $\mathrm{AOR}=4.918$ (95\%CI: 1.268-19.082). 
Table 1 Characteristics of respondents, duration on ARV and history of opportunistic infections

\begin{tabular}{lcc}
\hline Variables & $\mathbf{n}$ & $\%$ \\
\hline Quality of life & & \\
$\quad$ Low & 41 & 44.6 \\
High & 51 & 55.4 \\
Gender & & \\
$\quad$ Male & 53 & 57.6 \\
Female & 39 & 42.4 \\
Age (years) & & \\
$25-34$ & 25 & 27.2 \\
$35-44$ & 38 & 41.3 \\
$45-54$ & 23 & 25.0 \\
55 and above & 6 & 6.5 \\
Education & & \\
High & 55 & 59.8 \\
Low & 37 & 40.2 \\
Employment & & \\
Employed & 73 & 79.3 \\
Unemployed & 19 & 20.7 \\
Duration on ARV (years) & & \\
$\quad \leq 2$ & 20 & 21.7 \\
$>2$ & 72 & 78.3 \\
Opportunistic infections & & 59.8 \\
Yes & 55 & 40.2 \\
No & 37 & 100.0 \\
Total & 92 & \\
\hline
\end{tabular}

Table 2 Correlation matrix between emotional, instrumental, information and appraisal supports with quality of life of people living with HIV

\begin{tabular}{lccccc}
\hline & $\begin{array}{c}\text { Quality } \\
\text { of life }\end{array}$ & $\begin{array}{c}\text { Emotional } \\
\text { support }\end{array}$ & $\begin{array}{c}\text { Instrumental } \\
\text { support }\end{array}$ & $\begin{array}{c}\text { Information } \\
\text { support }\end{array}$ & $\begin{array}{c}\text { Appraisal } \\
\text { support }\end{array}$ \\
\hline $\begin{array}{l}\text { Quality of life } \\
\quad \text { Pearson correlation }(r)\end{array}$ & 1 & .267 & .092 & .253 & .147 \\
$\quad \begin{array}{l}\text { p-value } \\
\text { Emotional support }\end{array}$ & & .01 & .39 & .02 & .16 \\
$\quad \begin{array}{l}\text { Pearson correlation }(r) \\
\text {-value }\end{array}$ & .267 & & & & \\
$\begin{array}{l}\text { Instrumental support } \\
\quad \text { Pearson correlation }(r)\end{array}$ & .01 & 1 & .769 & .647 & .853 \\
$\quad$-value & .092 & .769 & .00 & .00 & .00 \\
Information support & .39 & .00 & 1 & .780 & .759 \\
$\quad \begin{array}{l}\text { Pearson correlation }(r) \\
\text { p-value }\end{array}$ & .253 & .647 & .780 & .00 & .00 \\
Appraisal support & .02 & .00 & .00 & 1 & .665 \\
$\quad \begin{array}{l}\text { Pearson correlation }(r) \\
\text { p-value }\end{array}$ & .147 & .853 & .759 & .665 & .00 \\
\hline
\end{tabular}


Table 3 Association between emotional, instrumental, information and appraisal support with people living with HIV quality of life

\begin{tabular}{lcccc}
\hline & \multicolumn{2}{c}{ Quality of life } & n (\%) & p \\
\cline { 2 - 3 } Supports & $\begin{array}{c}\text { High } \\
\mathbf{n}(\%)\end{array}$ & $\begin{array}{c}\text { Low } \\
\mathbf{n}(\%)\end{array}$ & & \\
\cline { 2 - 3 } Emotional & & & & \\
$\quad$ High & $18(62.1)$ & $11(37.9)$ & $29(31.5)$ & 0.38 \\
$\quad$ Moderate & $22(57.9)$ & $16(42.1)$ & $38(41.3)$ & \\
Low & $11(44.0)$ & $14(56.0)$ & $25(27.2)$ & \\
Instrumental & & & & \\
High & $23(65.7)$ & $12(34.3)$ & $35(38.0)$ & \\
Moderate & $16(43.2)$ & $21(56.8)$ & $37(40.2)$ & \\
Low & $12(60.0)$ & $8(40.0)$ & $20(21.7)$ & \\
Information & & & & \\
High & $32(59.3)$ & $22(40.7)$ & $54(58.7)$ & \\
Moderate & $9(42.9)$ & $12(57.1)$ & $21(22.8)$ & \\
Low & $10(58.8)$ & $7(41.2)$ & $17(18.5)$ & \\
Appraisal & & & & \\
$\quad$ High & $20(64.5)$ & $11(35.5)$ & $31(33.7)$ & \\
Moderate & $21(47.7)$ & $23(52.3)$ & $44(47.8)$ & \\
Low & $10(58.8)$ & $7(41.2)$ & $17(18.5)$ & \\
Total & $51(55.4)$ & $42(44.5)$ & $92(100.0)$ & \\
\hline
\end{tabular}

Table 4 Adjusted odd ratio of emotional, instrumental, information and appraisal support with quality of life of people living with HIV

\begin{tabular}{|c|c|c|c|c|}
\hline \multirow[b]{2}{*}{ Variables } & \multirow[b]{2}{*}{ AOR } & \multicolumn{2}{|c|}{$95 \% \mathrm{Cl}$} & \multirow[b]{2}{*}{$\mathbf{p}$} \\
\hline & & Lower & Upper & \\
\hline \multicolumn{5}{|l|}{ Gender } \\
\hline Female & Ref & 0.338 & 2.537 & 0.88 \\
\hline Male & 0.925 & & & \\
\hline \multicolumn{5}{|l|}{ Age (years) } \\
\hline $25-34$ & Ref & & & \\
\hline $35-44$ & 1.042 & 0.606 & 1.793 & 0.88 \\
\hline \multicolumn{5}{|l|}{$45-54$} \\
\hline \multicolumn{5}{|l|}{55 above } \\
\hline \multicolumn{5}{|l|}{ Education } \\
\hline High & Ref & & & \\
\hline Low & 0.712 & 0.263 & 1.931 & 0.51 \\
\hline \multicolumn{5}{|c|}{ Employment status } \\
\hline Unemployed & Ref & & & \\
\hline Employed & 0.726 & 0.218 & 2.419 & 0.60 \\
\hline \multicolumn{5}{|c|}{ Length of time on ARV } \\
\hline$\leq 2$ years & Ref & & & \\
\hline$>2$ years & 1.366 & 0.443 & 4.207 & 0.59 \\
\hline \multicolumn{5}{|c|}{ Opportunistic infections } \\
\hline No & Ref & & & \\
\hline
\end{tabular}


Table 4 Continue

\begin{tabular}{|c|c|c|c|c|}
\hline \multirow[b]{2}{*}{ Variables } & \multirow[b]{2}{*}{ AOR } & \multicolumn{2}{|c|}{$95 \% \mathrm{Cl}$} & \multirow[b]{2}{*}{$\mathbf{p}$} \\
\hline & & Lower & Upper & \\
\hline Yes & 0.524 & 0.196 & 1.401 & 0.20 \\
\hline \multicolumn{5}{|c|}{ Emotional support } \\
\hline Low & Ref & & & \\
\hline High & 4.925 & 1.273 & 19.052 & 0.02 \\
\hline \multicolumn{5}{|c|}{ Instrumental support } \\
\hline Low & Ref & & & \\
\hline High & 0.865 & 0.228 & 3.278 & 0.83 \\
\hline \multicolumn{5}{|c|}{ Information support } \\
\hline Low & Ref & & & \\
\hline High & 0.949 & 0.248 & 3.637 & 0.94 \\
\hline \multicolumn{5}{|c|}{ Appraisal support } \\
\hline Low & Ref & & & \\
\hline High & 0.317 & 0.095 & 1.057 & 0.06 \\
\hline
\end{tabular}

\section{DISCUSSION}

In our study, emotional support was measured by awareness, willingness to listen to problems, encouragement, comfort from spouses, family, friends and health workers. Instrumental support included aids provided to people living with HIV, including facilities, finance, medicine, food, vehicles and services. Information support is all information obtained by people living with HIV from family, friends, spouses and health workers about the results of the test, reminders on how to take the right medicine and how to maintain health. Appraisal support is measured by praise or a sense of being respected by family, friends, spouses and health workers.

In our study, the people living with HIV quality of life was only found to be significantly associated with emotional support and there was no association with instrumental, information and appraisal supports. This is due to the presence of collinearity, which is the strong association between independent variables as shown in Table 2. Some published studies indicate that emotional support affects the quality of life of people living with HIV. A study in Europe (EUROSUP-PORT V Study), shows that emotional supports are significantly related to quality of life, namely by depression and anxiety mitigation. ${ }^{20}$

A study conducted among HIV+ pregnant women in Thailand shows that lack of emotional support is significantly related to depressive symtoms. ${ }^{21}$ Some other studies show that the quality of life of people living with HIV is influenced by emotional and informational support. A study in Nepal shows that emotional and informational supports were found as predictors of the quality of life of people living with HIV. ${ }^{9}$ A study in China shows that emotional and informational supports are significant predictors of depression, mobility and psychological aspects connected to the quality of life of people living with HIV. ${ }^{22}$

In our study, no association was found between instrumental, appraisal and informational supports with the quality of life of people living with HIV. Several published studies found a significant association between family support and the quality of life of people living with HIV, in which the family supports are in the form of assistance in the treatment and care and access to any health facilities needed by people living with HIV. ${ }^{23}$ Another study conducted in the VCT Sehati Clinic at dr. T.C. Hillers Hospital, Maumere shows a significant association between family support and quality of life of people living with HIV. Most of them received family support during ARV treatment in the form of physical, psychological, informational and social supports. ${ }^{24}$

The limitations of this study are that samples consisted only of non-key population people living with HIV in an NGO clinic in Denpasar and the high collinearity between independent variables.

\section{CONCLUSION}

Emotional support is the only element of social support that associated with the quality of life of people living with HIV. Emotional support needs to be enhanced to further improve the quality of life of people living with HIV. 


\section{ACKNOWLEDGEMENT}

We would like to thank the Director of the Kerti Praja Foundation and all respondents who participated in this study.

\section{REFERENCES}

1. UNAIDS. Factsheet-july 2018 Global HIV Statistics (2017). 2018; (July):1-5. Available from: http:// www.unaids.org/sites/default/files/media_asset/ UNAIDS_FactSheet_en.pdf

2. Ministry of Health of Indonesia. Laporan perkembangan HIV-AIDS \& infeksi menular seksual (IMS) triwulan IV tahun 2017 [The IV quarterly report on the progress of HIV-AIDS and sexually transmitted infections year 2017]. 2018; Jakarta.

3. Bali Province Health Office. Kumulatif kasus HIVAIDS dari tahun 1987-Desember 2018 di Provinsi Bali [Cumulative number of HIV-AIDS cases from 1987 to December 2018 in Bali Province] [Internet]. Denpasar; 2018. Available from: https://tinyurl.com/ data-kasus-hiv-bali

4. UNAIDS. Regional HIV statistics-2016. 2017; (July):1-8.

5. UNAIDS. UNAIDS Terminology Guidelines [Internet]. 2015. Available from: www.unaids.org/.../2015 terminology_guidelines_en.pdf

6. Data UNAIDS [Internet]. 2018. Available from: http:// www.unaids.org/sites/default/files/media_asset/ unaids-data-2018 en.pdf

7. Brinkhof MWG, Pujades-rodriguez M, Egger M. Mortality of patients lost to follow-up in antiretroviral treatment programmes in resource-limited settings: systematic review and meta-analysis. PloS One. 2009;4(6).

8. Januraga PP, Reekie J, Mulyani T, Lestari BW, Iskandar S, Wisaksana R, et al. The cascade of HIV care among key populations in Indonesia: a prospective cohort study. Lancet HIV [Internet]. 2018; 3018(18):1-9.

9. Yadav S. Perceived social support, hope and quality of life of persons living with HIV/AIDS: A case study from Nepal. Quality of Life Research. 2010;19(2):157-66.

10. Charkhian A, Fekrazad H, Sajadi H, Rahgozar M. Relationship between health-related quality of life and social support in HIV-infected people in Tehran, Iran. Iranian Journal of Public Health. 2014;43(1):100-6.

11. Jia H, Uphold CR, Wu S, Reid K, Findley K, Duncan PW. Health-related quality of life among men with HIV infection: Effects of social support, coping, and depression. AIDS Patient Care and STDs [Internet]. 2004;18(10):594-603.

12. Heaney CA, Israel BA. Social networks and social support. in: Glanz K, Lewis FM, Rimer BK (eds) Health behavior and health education: theory, research and practice, $2^{\text {nd }}$ ed. 1997. Jossey-Bass Publishers, San Francisco, pp 179-205

13. Diatmi K, Diah IGA. Hubungan antara dukungan sosial dengan kualitas hidup pada orang dengan HIV dan AIDS (odha) di Yayasan Spirit Paramacitta [The association of social support and quality of life in people living with HIV and AIDS in Spirit Paramacitta Foundation]. Jurnal Psikologi Udayana. 2014;1(2):353-62.

14. Astuti A, Budiyani K. Hubungan antara dukungan sosial yang diterima dengan kebermaknaan hidup pada odha (orang dengan HIV/AIDS) [The association of social support and quality of life in people living with HIV/AIDS]. 1999; Available at: http://fpsi.mercubuana-yogya.ac.id/ wp-content/uploads/2012/06/Agustus_ 2010_KondangBudiyani.pdf
15. Rozi RF. Hubungan dukungan sosial dengan kualitas hidup ODHA pada Kelompok Dukungan Sebaya Solo Plus di Surakarta (Skripsi) [The association of social support and quality of life of people living with HIV/AIDS in the Solo Plus Peer Support Group in Surakarta (Undergraduate thesis)]. Universitas Muhammadiyah. 2016; Available at: http://eprints.ums.ac.id/42459/2/halaman\%20depan.pdf

16. Sun W, Wu M, Qu P, Lu C, Wang L. Quality of life of people living with HIV/AIDS under the new epidemic characteristics in China and the associated factors. PLOS ONE. 2013; $8(5)$.

17. Ministry of Health of Indonesia. Profil Kesehatan Indonesia [Indonesia Health Profile] [Internet]. Jakarta; 2004. Available from: http://www.depkes.go.id/download. php?file=download/pusdatin/profil-kesehatan-indonesia/ profil-kesehatan-indonesia-2004.pdf

18. World Health Organization. The world health organization quality of life (WHOQOL)-bref: Introduction, administration, scoring and generic version of the assessment. 1996: Geneva. Available at: https://www.who.int/mental_health/ media/en/76.pdf

19. Khairunnisa DA, Firdaus I. Efektifitas dukungan sosial bagi ODHA (orang dengan HIV/AIDS) di Kelompok Dukungan Sebaya Kuldesak Kota Depok (Skripsi). [The effectiveness of social support for people living with HIV/ AIDS in Kuldesak Peer Support Group in Depok City (Undergraduate thesis)]. 2015; Fakultas Ilmu Dakwah dan Ilmu Komunikasi, Universitas Islam Negeri Syarif Hidayatullah. Jakarta.

20. Gordillo V, Fekete E, Platteau T, Antoni MH, Schneiderman N, Nöstlinger C. Emotional support and gender in people living with HIV: Effects on psychological well-being. Journal of Behavioral Medicine. 2009; 32:523.

21. Ross R, Kleman C, Saenyakul P, Stidham AW, Nursing C. Path analysis of physical symptoms, emotional support, self-esteem and depressive symptoms in HIV-positive perinatal women in Thailand. Journal of Clinical Research in HIV/AIDS and Prevention. 2014. 2(1):12-26.

22. Xiao Z, Li X, Qiao S. Social support, depression and quality of life among people living with HIV in Guangxi, China. HHS Public Access. 2017; 29(3): 319-25.

23. Novrianda D, Nurdin Y, Ananda G. Dukungan keluarga dan kualitas hidup orang dengan HIV/AIDS di Lantera Minangkabau [Family support and quality of life of people living with HIV/AIDS in Lantera Minangkabau]. Jurnal Ilmu Keperawatan Medial Bedah. 2018; 1(1): 1-43.

24. Avelina Y, Idwan. Hubungan antara dukungan keluarga dengan kualitas hidup pasien HIV/AIDS yang menjalani terapi di Klinik VCT Sehati RSUD dr. T.C. Hillers Maumere. Prosiding Seminar Nasional. 2018; 93-103. Fakultas Ilmu Kesehatan, Universitas Muhammadiyah Jember.

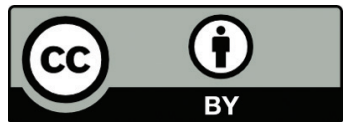

This work is licensed under a Creative Commons Attribution 